\title{
Accelerated corrosion performance of AISI 316L stainless steel concrete reinforcement used in restoration works of ancient monuments
}

\author{
Sofia Tsouli ${ }^{1}$, Angeliki G. Lekatou ${ }^{1, *}$, Evangelos Siozos ${ }^{1}$, and Spyridon Kleftakis ${ }^{1}$ \\ ${ }^{1}$ Laboratory of Applied Metallurgy, Department of Materials Science and Engineering, School of \\ Engineering, University of Ioannina, 45110 Ioannina, Greece
}

\begin{abstract}
The accelerated corrosion performance of AISI type $316 \mathrm{~L}$ stainless steel rebars in solutions simulating concrete exposed to various environments was studied by means of cyclic polarization, before and after a four month salt spray test. B500A structural steel rebars were also tested for comparison reasons. Although $316 \mathrm{~L}$ showed some susceptibility to localized corrosion during polarization in saturated $\mathrm{Ca}(\mathrm{OH})_{2}$ containing 3.5 wt. $\% \mathrm{NaCl}$, four months of salt spraying did not significantly affect its polarization behavior. Salt spraying for $4 \mathrm{~m}$ did not have any significant effect on the macrostructural state of $316 \mathrm{~L}$ reinforced concrete.
\end{abstract}

\section{Introduction}

Reinforced concrete is currently the most predominant material used for the construction of the load bearing elements of structures, as it is economical, versatile, exhibits long lifetime, high mechanical properties and durability [1-4]. Although it performs very well during its service life, the rapid deterioration of the construction service life and seismic resistance due to corrosion of the steel reinforcement is nowadays a critical problem. Corrosion is due to either chloride penetration into the concrete through its pores or concrete carbonation (by the reaction between atmospheric $\mathrm{CO}_{2}$ and $\left.\mathrm{Ca}(\mathrm{OH})_{2}\right)$. Both mechanisms cause localized corrosion and depassivation of the protective oxide film of the steel rebar [3-11]. Corrosion affects not only the appearance of the structure, but also its strength and safety, with subsequent reduction of the reinforcement cross-sectional area and mechanical properties; this way, both the overall structure performance and the surrounding concrete/steel bond strength deteriorate $[5,8,12,13]$.

Many historical buildings and monuments are located in coastal and urban regions, where high $\mathrm{Cl}^{-}$and $\mathrm{CO}_{2}$ concentrations are, respectively, observed. Therefore, the reinforced concrete used for their restoration is subjected to deterioration $[5,6,14]$. The application of modern materials, such as stainless steels and titanium, in ancient monument restoration works is one of the most reliable methods to extend the lifetime of reinforced concrete in highly aggressive environments $[1,4,7,8,11]$. A characteristic application is the employment of $316 \mathrm{~L}$ stainless steel as concrete reinforcement for coupling ancient

* Corresponding author: alekatou@cc.uoi.gr 
architectural members in the ancient theater of Dodona in Greece. The replacement of conventional steel reinforcement with corrosion-resistant stainless steels can decrease maintenance costs over $50 \%$ and extend the lifetime of reinforced concrete more than 100 years [7].

316L stainless steel finds widespread application in many fields of human activity, such as marine and architectural constructions, chemical and petrochemical industries, food industry and, generally, many fields of human activity [15-17]. This is due to the fact that it combines high corrosion resistance to localised and uniform corrosion compared to more conventional austenitic stainless steels (e.g. 304, 316 types), with good mechanical properties (mechanical strength, creep resistance, ductility) and weldability) $[15,16]$. The good corrosion behavior is attributed to the chromia-based passive film formed on the surface of the steel $[8,11,15-18]$, as well as the beneficial action of molybdenum, which improves the resistance to localized corrosion in chloride containing environments and nickel, which stabilizes the passive state of the steel $[15,16,18,19]$.

Austenitic stainless steels are susceptible to localized corrosion in chloride containing environments, due to the breakdown of the passive film by the $\mathrm{Cl}^{-}$ions. The most important factors for the corrosion behavior of $316 \mathrm{~L}$ in such solutions are the chloride concentration $[16,20-22]$, the $\mathrm{pH}[20,22]$ and the temperature $[16,20,22]$. Regarding the corrosion response of $316 \mathrm{~L}$ in solutions simulating porous concrete in marine environment, it has been reported to mostly be affected by the $\mathrm{pH}$ of the solution $[8,11,23]$ and the chloride concentration $[7,23]$.

The corrosion mechanisms of stainless steel have been attracting great research interest. Few studies, nevertheless, are reported dealing with the corrosion mechanisms of concrete reinforcement stainless steel by means of advanced electrochemical techniques, after intensive environmental stress, as well as with the study of the mechanical behavior of corroded stainless steel $[7,8,11,23]$. Despite the high resistance of stainless steel to corrosion, especially when embedded in concrete, an exceptional localized corrosion behavior is a prerequisite when dealing with cultural inheritage in environmentally stressed regions (saline, urban, near industries, airports, etc.). Access of aggressive ions being present in these environments, such as $\mathrm{Cl}^{-}, \mathrm{SO}_{4}{ }^{2-}, \mathrm{HCO}_{3}{ }^{-}, \mathrm{CO}_{4}{ }^{2-}$, etc., to the steel surface through the concrete may induce severe localized corrosion.

The present study is part of a wider effort to evaluate the sufficiency of $316 \mathrm{~L}$ stainless steel concrete reinforcement for long term application to restoration works of ancient monuments in both mild and aggressive environments. In particular, the present work deals with the electrochemical performance of $316 \mathrm{~L}$ rebars embedded in concrete or immersed in concrete simulating solutions, before and after salt spray testing, in order to mimic extremely aggressive conditions (corrosion-wise).

\section{Experimental}

Rebars of 316L stainless steel (nominal composition in wt.\%: C: 0.022, Cr: 17.31, Ni: 10.08, Si: 0.54, Mn: 1.75, Mo: 2.02, P: 0.0032, S: 0.0001) of $6 \mathrm{~mm}$ diameter and $1.5 \mathrm{~cm}$ length were used for electrochemical testing. Simultaneously, rebars of B500A steel (nominal composition in wt.\%: C: 0.24, S: 0.055, P: 0.055, N: 0.014, Cu: 0.85, Ceq: 0.52) of $8 \mathrm{~mm}$ diameter and $1.5 \mathrm{~cm}$ length were also subjected to electrochemical testing for comparison reasons. Potentiodynamic polarization tests were conducted on the $316 \mathrm{~L}$ and B500A rebars, both cutting edges of which had been coated by epoxy and masked in PTFE (three electrode cell, $\mathrm{Ag} / \mathrm{AgCl} / 3.5 \mathrm{M} \mathrm{KCl}, \mathrm{Pt}, 4 \mathrm{~h}$ immersion under open circuit to reach steady state, room temperature, $10 \mathrm{mV} / \mathrm{min}$ scan rate, ACM-Gill AC potentiostat/galvanostat) before and after a $3 \mathrm{~m}$ and $4 \mathrm{~m}$ salt spray testing. More information on the experimental procedure can be sought in [24-26]. The corrosion current 
densities were calculated by Tafel extrapolation, adopting several restrictions analytically reported in previous works $[24,25]$. The susceptibility of the steels to localized corrosion was investigated by cyclic polarization, according to ASTM G61-86 [27]. Three naturally aerated aqueous solutions were employed as electrolytes: (a) 3.5 wt. $\% \mathrm{NaCl}$, saturated (s.) $\mathrm{Ca}(\mathrm{OH})_{2}$ and (c) saturated (s.) $\mathrm{Ca}(\mathrm{OH})_{2}$ with $3.5 \mathrm{wt} . \% \mathrm{NaCl}$. The first solution simulates saline / marine environments $[4,11]$, while the other two simulate concrete pore environments in mild and aggressive environmental conditions, respectively $[1,4,7-9,11$, 28]. This simulation is based on the fact that $\mathrm{Ca}(\mathrm{OH})_{2}$ crystals can occupy approximately $20 \%-25 \%$ of the cement paste volume [28]. After the necessary metallographic preparation, the microstructure of the specimens (cross-sections) was examined by SEM (Scanning Electron Microscopy)/EDX (Energy Dispersion X-ray spectroscopy) (JeoL JSM 6510 LV SEM / Oxford Instruments X- Act EDX).

Specimens of $316 \mathrm{~L}$ rebars were subjected both directly $(1.5 \mathrm{~cm}$ long) and embedded (10 cm long) in Portland concrete cubes to salt spraying for $4 \mathrm{~m}$ (Vötch Ind. GmbH, ASTM B117-97 [29]). Rebars of B500A steel (10 cm long), embedded in concrete cubes, were also subjected to salt spraying for comparison reasons.

\section{Results - Discussion}

\subsection{Cyclic potentiodynamic polarization}

Figs. $1 \mathrm{a}$ and $1 \mathrm{~b}$ depict representative cyclic potentiodynamic polarization curves for $316 \mathrm{~L}$ and $\mathrm{B} 500 \mathrm{~A}$ rebars, before and after salt spraying, in $3.5 \mathrm{wt} . \% \mathrm{NaCl}$ and s. $\mathrm{Ca}(\mathrm{OH})_{2}$ with 3.5 wt. $\% \mathrm{NaCl}$, respectively. Regarding $316 \mathrm{~L}$, the similar shapes of the curves in both environments reflect the likeliness in the corrosion behaviors. In further detail, all curves include passive stages of true passivity (passive currents $<0.1 \mathrm{~mA} / \mathrm{cm}^{2}$ ). Breakdown occurs at potentials $\left(\mathrm{E}_{\mathrm{b}}\right)$ over a $1000 \mathrm{mV}$ higher than $\mathrm{E}_{\text {corr }}$ indicating that the breakdown of passivity is due to transpassive dissolution rather than localised corrosion [30]. However, the sharp increase in the current density at $E_{b}$ that is sustained for a couple orders of current magnitude does not exclude the possibility of some localised corrosion during the process of transpassive dissolution. This possibility is enhanced by the negative hysteresis loops of the anodic polarization curves (i.e. higher current densities upon reverse polarization as compared to the forward polarization for the same potential) above the middle of the passive stage. Nevertheless, the anodic-to-cathodic transition potentials $\left(E_{a / c}\right.$ tr $)$ are nobler than the corrosion potential $\left(\mathrm{E}_{\mathrm{corr}}\right)$, indicating nobler surfaces at $\mathrm{E}_{\mathrm{a} / \mathrm{c}}$ tr upon reverse polarization than those at $\mathrm{E}_{\text {corr }}$ upon forward polarization. In both aggressive environments, the negative hysteresis has turned into a positive one suggesting that the degradation caused by localized corrosion was reversible. Similar corrosion behavior has also been noticed by Ezuber [16] and Yi et al. [31], who studied the corrosion performance of 316L stainless steel in 3.5 wt.\% $\mathrm{NaCl}$, as well as, Blanco et al. [1] and Luo [11], who conducted cyclic polarizations in saturated $\mathrm{Ca}(\mathrm{OH})_{2}$ containing $\mathrm{NaCl}$ solution.

Figs. $1 \mathrm{a}$ and $1 \mathrm{~b}$ show that the only notable effect of $3-4$ month salt spraying is a limited shift of the forward polarization curves to higher current densities. Otherwise, the cyclic polarization performance has not been significantly affected. 

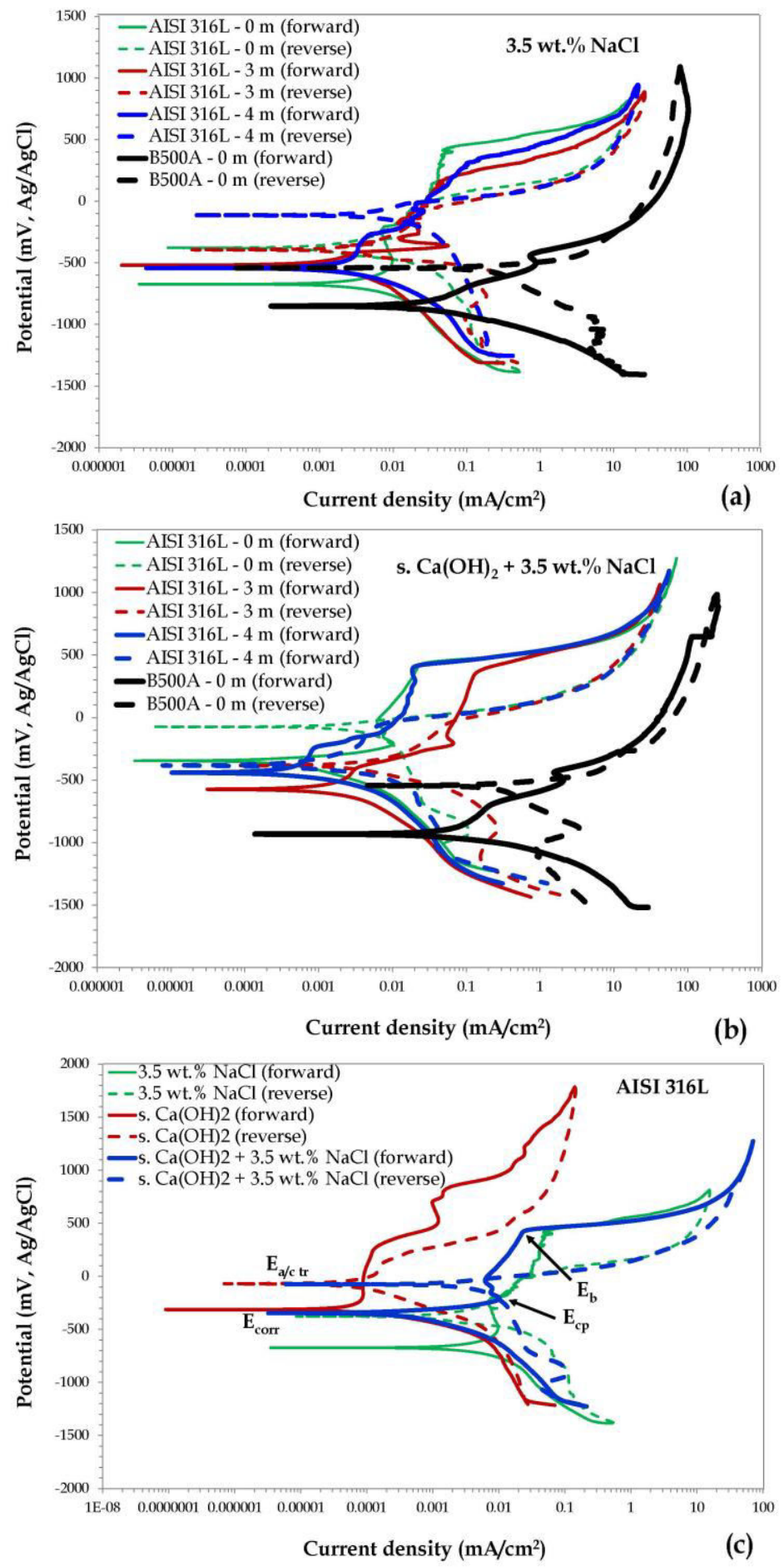

Fig. 1. Cyclic voltammograms of $316 \mathrm{~L}$ and $\mathrm{B} 500 \mathrm{~A}$ rebars in (a) $3.5 \mathrm{wt} . \% \mathrm{NaCl}$ and (b) s. $\mathrm{Ca}(\mathrm{OH})_{2}+$ 3.5 wt. $\% \mathrm{NaCl}$, before and after salt spray testing. (c) Comparison of the three environment effect before salt spraying. $\mathrm{E}_{\mathrm{corr}}$ : Corrosion potential, $\mathrm{E}_{\mathrm{cp}}$ : Critical passivation potential, $\mathrm{E}_{\mathrm{b}}$ : Breakdown potential, $\mathrm{E}_{\mathrm{a} / \mathrm{c} \text { tr }}$ : Anodic-to-cathodic transition potential. 
Comparison of the voltammograms of $316 \mathrm{~L}$ with those of B500A rebars before salt spraying (Figs. 1a, 1b), manifests higher corrosion resistance of $316 \mathrm{~L}$ rebars as compared to B500A rebars, in terms of slower corrosion kinetics (shift of polarization curves of B500A to current densities that are nearly 3 orders of current magnitude greater than those of $316 \mathrm{~L}$ ) and less thermodynamic tendency for corrosion (nobler $\mathrm{E}_{\text {corr }}$ ). The superiority of the corrosion performance of $316 \mathrm{~L}$ rebar over that of B500A rebar is mainly attributed to the presence of $\mathrm{Cr}$, Mo and $\mathrm{Ni}$ and the lower content of $\mathrm{S}$ in $316 \mathrm{~L}$. Cr creates the passive surface film, Mo improves the resistance to localized corrosion in chloride containing environments and Ni promotes the stabilization of the passive film. Sulfur, on the other hand, in the form of sulfides promotes pit corrosion [15].

Fig. 1c illustrates the effect of three different environments in the polarization behavior of $316 \mathrm{~L}$ rebars. It is obvious that $\mathrm{Cl}^{-}$concentration increases the kinetics of the electrochemical reactions, as it has led to a shift of the curves to higher current densities. The corrosion rate increases with $\mathrm{Cl}^{-}$concentration increasing $\left(\mathrm{i}_{\text {cor }}\left(\mathrm{s} . \mathrm{Ca}(\mathrm{OH})_{2}\right)=\right.$ $9 \times 10^{-5} \mathrm{~mA} / \mathrm{cm}^{2}, \mathrm{i}_{\text {cor }}\left(\mathrm{s.} \mathrm{Ca}(\mathrm{OH})_{2}+3.5 \mathrm{wt} . \% \mathrm{NaCl}\right)=4 \times 10^{-4} \mathrm{~mA} / \mathrm{cm}^{2}, \mathrm{i}_{\text {cor }}(3.5 \mathrm{wt} . \% \mathrm{NaCl})$ $\left.=6 \times 10^{-3} \mathrm{~mA} / \mathrm{cm}^{2}\right)$. This shows that the environment of $\mathrm{Ca}(\mathrm{OH})_{2}$ seriously delayed, but did not stop the adsorption of chloride ions into the surface of the steel. $316 \mathrm{~L}$ in $3.5 \mathrm{wt} . \% \mathrm{NaCl}$ exhibits metastable pitting in a high range of "passive" potentials. True passivity (i.e. $\mathrm{i}_{\mathrm{p}}<$ $0.1 \mathrm{~mA} / \mathrm{cm}^{2}$ ) is not attained only in $3.5 \mathrm{wt} . \% \mathrm{NaCl}$. The above observations confirm that $\mathrm{Cl}^{-}$ ions are responsible for the increase in pitting corrosion by decreasing the stability of the passive film on the steel surface. The least degradation was caused by $\mathrm{s} . \mathrm{Ca}(\mathrm{OH})_{2}$, as it is shown by the presence of passivation in a great range of anodic potentials, decreased corrosion current densities and nobler corrosion potentials. On the other hand, the most aggressive environment was that of $3.5 \mathrm{wt} . \% \mathrm{NaCl}$, as expected.

\subsection{Salt spray test}

Figs. $2 \mathrm{a}-2 \mathrm{f}$ present the state of a representative $316 \mathrm{~L}$ rebar during salt spraying for $4 \mathrm{~m}$. All specimens were received almost intact. Few specimens presented some corrosion indications (rust) on the surface of the steel, limited to the ribs close to the edges of the specimen, probably due to iron oxidation in the work hardened ribs. Although the edges of the specimens were embedded in epoxy resin, limited rust was observed by the edges (most likely on microcracks), without, however, being spread out across the surface of the steel. The edges, due to the dry cutting process, are highly susceptible to stress corrosion cracking [15]. Consequently, in naked eye, salt spray testing did not significantly influenced the surface of the steel specimens.

Fig. 3 presents the states of 316L and B500A reinforced concrete cubes after exposure into the salt spray chamber for $4 \mathrm{~m}$ and $7 \mathrm{~d}$, respectively. The fine state of the $316 \mathrm{~L}$ reinforced concrete specimen is obvious even after $4 \mathrm{~m}$ of salt spraying. Conversely, the B500A reinforced concrete cube presented rust at the steel/concrete interface (site of introduction to the concrete). 

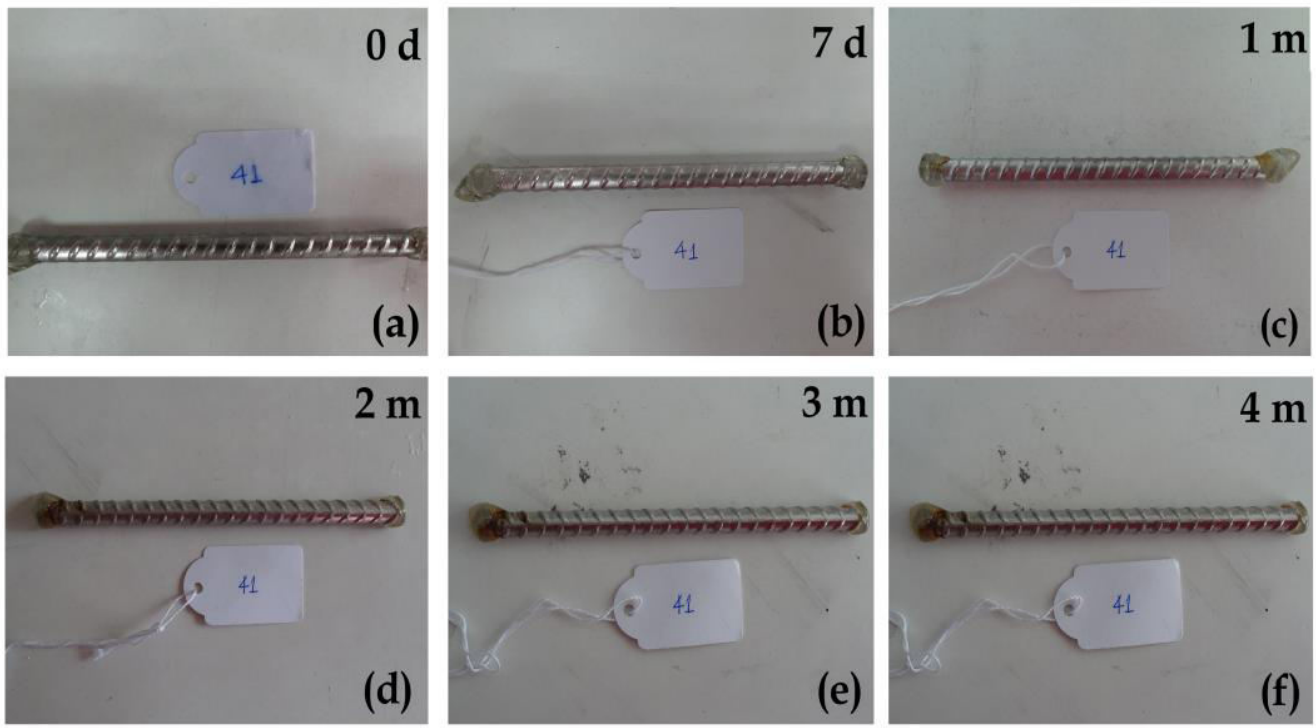

Fig. 2. 316L rebars (a) before salt spraying, (b) after $7 \mathrm{~d}$, (c) after $1 \mathrm{~m}$, (d) after $2 \mathrm{~m}$, (e) after $3 \mathrm{~m}$ and (f) after $4 \mathrm{~m}$ in the salt spray chamber
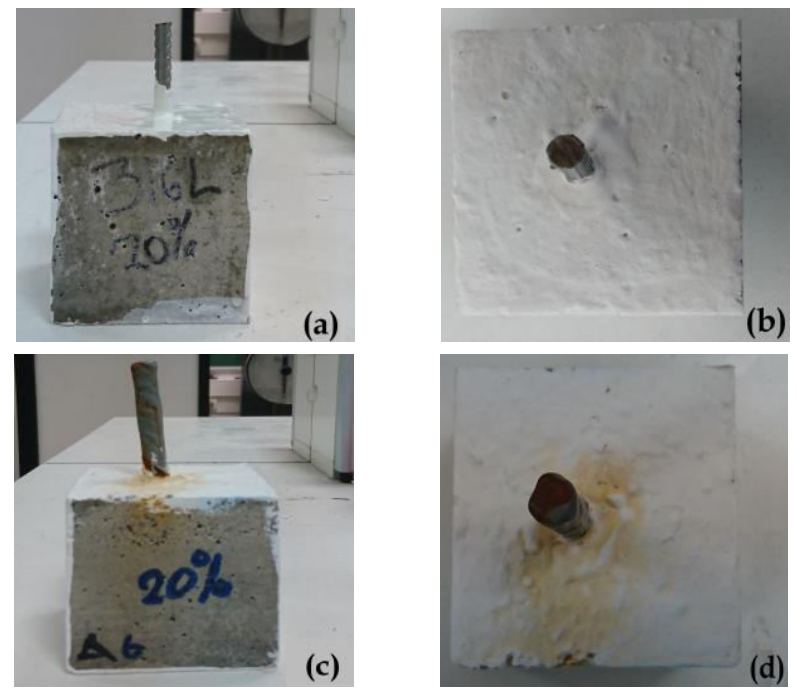

Fig. 3. 316L (upper) \& B500A (lower) reinforced concrete cubes after $4 \mathrm{~m}$ and $7 \mathrm{~d}$, respectively in the salt spray chamber. (a) \& (c) side-view; (b) \& (d) top-view.

\subsection{Microstructure of corroded specimens}

Fig. 4 presents the cross-sectional microstructure of $316 \mathrm{~L}$ rebars, after salt spraying for $4 \mathrm{~m}$, followed by cyclic potentiodynamic polarization in $3.5 \mathrm{wt} . \% \mathrm{NaCl}$. Fig. 4 manifests the excellent state of the surface of the stainless steel (even though the magnification is quite small corresponding to a large surface area). Not any indications of localized corrosion can be seen. On the contrary, a compact passive film on the steel surface of the steel is clearly distinguished. 

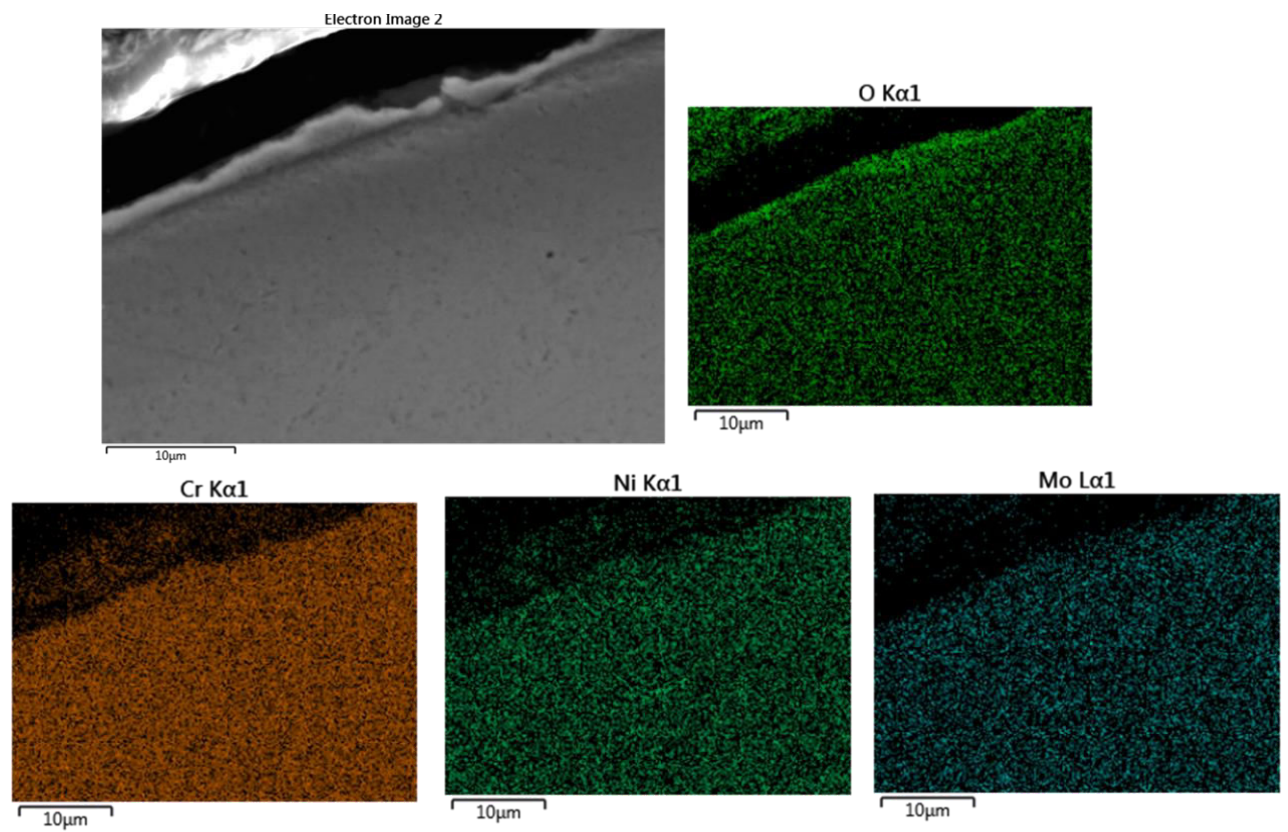

Fig. 4. Cross-section of 316L rebar after cyclic polarization in $3.5 \mathrm{wt} \% \mathrm{NaCl}$ following a $4 \mathrm{~m}$ salt spray test.

\section{Conclusions}

(1) Cyclic polarization of $316 \mathrm{~L}$ concrete reinforcing bars (rebars) in $3.5 \mathrm{wt} . \% \mathrm{NaCl}$ and porous concrete simulating environments $\left(\mathrm{s} . \mathrm{Ca}(\mathrm{OH})_{2}\right.$ and s. $\mathrm{Ca}(\mathrm{OH})_{2}+3.5$ wt. $\left.\% \mathrm{NaCl}\right)$ revealed passivation and high resistance to localized corrosion. There were indications of localised corrosion; nevertheless, localised corrosion was reversible during reverse polarization.

(2) The superiority of $316 \mathrm{~L}$ concrete reinforcement with respect to B500A in terms of cyclic polarization behavior was manifested by the notably slower corrosion kinetics and less thermodynamic tendency for corrosion (nobler $\mathrm{E}_{\text {corr }}$ ).

(3) Salt spraying for $4 \mathrm{~m}$ had a minor effect on the electrochemical performance of the $316 \mathrm{~L}$ rebars.

(4) $\mathrm{The} \mathrm{Cl}^{-}$presence in the electrolyte increased the kinetics of the electrochemical reactions and decreased the stability of the passive film on the stainless steel surface.

(5) The $\mathrm{Ca}(\mathrm{OH})_{2}$ environment obstructed, but did not prevent the adsorption of chloride ions into the surface of the steel.

(6) Salt spraying for $4 \mathrm{~m}$ did not have any significant effect on the macrostructural state of 316L reinforced concrete. In contrast, B500A reinforced concrete presented signs of corrosion after 7 days of salt spraying (at the site of introduction to the concrete, though).

\section{References}

1. G. Blanco, A. Bautista, H. Takenouti, Cement Concrete Comp. 28, 212-219 (2006)

2. M. Mahdikhani, O. Bamshad, M. Fallah Shirvani, Constr. Build. Mater. 167, 929-935 (2018)

3. A. Zacharopoulou, E. Zacharopoulou, G. Batis, Open J. Met. 4, 86-92 (2014)

4. H. Luo, X. Wang, C. Dong, K. Xiao, X. Li, Corros. Sci. 124, 178-192 (2017) 
5. Ch.A. Apostolopoulos, S. Demis, V.G. Papadakis, Constr. Build. Mater. 38, 139-146 (2013)

6. A. Apostolopoulos, Th.E. Matikas, Int. J. Struct. Integr. 7, 240-259 (2016)

7. R.D. Moser, P.M. Singh, L.F. Kahn, K.E. Kurtis, Corros. Sci., 57, 241-253 (2012)

8. L. Freire, M.J. Carmezima, M.G.S. Ferreiraa, M.F. Montemor, Electrochim. Acta 55, 6174-6181 (2010)

9. E. Volpi, A. Olietti, M. Stefanoni, S.P. Trasatti, J. of Electroanal. Chem. 736, 38-46 (2015)

10. S. Sharifi-Asl, F. Mao, P. Lu, B. Kursten, D.D. Macdonald, Corros. Sci. 98, 708-715 (2015)

11. H. Luo, H. Su, C. Dong, X. Li, Appl. Surf. Sci. 400, 38-48 (2017)

12. S. Demis, K. Pilakoutas, Ch.A. Apostolopoulos, Mater. Corros. 61, 328-331 (2010)

13. S.M. Abd El Haleem, E.E. Abd El Aal, S. Abd El Wanees, A. Diab, Corros. Sci. 52, 3875-3882 (2010)

14. E. Rakanta, Th. Zafeiropoulou, G. Batis, Constr. Build. Mater. 44, 507-513 (2013)

15. A. Lekatou, Corrosion and protection of metals in simple words (Nemertes Publication, Athens, 2013) (in Greek)

16. H. M. Ezuber, Mater. Design 59, 339-343 (2014)

17. R.J.K. Wood, J.C. Walker, T.J. Harvey, S. Wang, S.S. Rajahram, Wear 306, 254-262 (2013)

18. S. Ningshen, U. Kamachi Mudali, G. Amarendra, P. Gopalan, R.K. Dayal, H.S.Khataka, Corros. Sci. 48, 1106-1121 (2006)

19. J. Biehler, H. Hoche, M. Oechsner, Surf. Coat. Technol. 313, 40-46 (2017)

20. K.V.S. Ramana, T. Anita, S. Mandal, S. Kaliappan, H. Shaikh, P.V. Sivaprasad, R.K. Dayal, H.S. Khatak, Mater. Design 30, 3770-3775 (2009)

21. A. Kocijan, Č. Donik, M. Jenko, Corros. Sci. 49, 2083-2098 (2007)

22. A.U. Malik, P.C. Mayan Kutty, N.A. Siddiqi, I.N. Andijani, S. Ahmed, Corros. Sci. 33, 1809-1827 (1992)

23. W. Miao, Z. Gao, W. Hu, Int. J. Electrochem. Sci. 13, 771-784 (2018)

24. A. Lekatou, A.K. Sfikas, A.E. Karantzalis, D. Sioulas, Corros. Sci. 63, 193-209 (2012)

25. A. Lekatou, D. Sioulas, A.E. Karantzalis, D. Grimanelis, Surf. Coat. Technol. 276, 539-556 (2015)

26. A. Lekatou, A.K. Sfikas, C. Petsa, A.E. Karantzalis, Metals 6 (2016) doi:10.3390/met6030046

27. ASTM G61-86, Standard Test Method for Conducting Cyclic Potentiodynamic Polarization Measurements for Localized Corrosion Susceptibility of Iron-, Nickel-, or Cobalt-Based Alloys (ASTM International, 2014)

28. I.S. El-Mahallawi, M.R. El Koussy, S.M. El Raghy, G. Megahed, M. Hashem, A.F. Waheed, O. Abd-Ellatif, Int. Heat Treat. Surf. Eng. 1, 126-137 (2007)

29. ASTM B117-97, Standard Practice for Operating Salt Spray (Fog) Apparatus, ASTM International (ASTM International, 1997)

30. A. Lekatou, E. Regoutas, A.E. Karantzalis, Corros. Sci. 50, 3389-3400 (2008)

31. Y. Yi, P. Cho, A. Al Zaadi, Y. Addad, C. Jang, Corros. Sci. 74, $92-97$ (2013) 